American Journal of Biological and Environmental Statistics
2017;3(4): $54-64$
http://www.sciencepublishinggroup.com/j/ajbes
doi: 10.11648 /j.ajbes.20170304.13
ISSN: $2471-9765$ (Print); ISSN: $2471-979 \mathrm{X}$ (Online)

\title{
Study of Nutrient Salts, Chlorophyll-a and Physicochemical Condition in El-Mex Bay Water, Alexandria, Egypt
}

\author{
Mohamed A. Okbah ${ }^{1}$, Mamdouh S. Masoud ${ }^{2}$, Gehan M. El Zokm ${ }^{1}$, Alyaa A. Abd El-Salam ${ }^{1}$ \\ ${ }^{1}$ Marine Chemistry Department, National Institute of Oceanography and Fisheries, Alexandria, Egypt \\ ${ }^{2}$ Chemistry Department, Faculty of Science, Alexandria University, Alexandria, Egypt
}

Email address:

m_okbah@yahoo.com (M. A. Okbah),drmsmasoud@yahoo.com (M. S. Masoud), gehanelzokm@yahoo.com (G. M. El Zokm), aliaa.ali47@yahoo.com (A. A. A. El-Salam)

\section{To cite this article:}

Mohamed A. Okbah, Mamdouh S. Masoud, Gehan M. El Zokm, Alyaa A. Abd El-Salam. Study of Nutrient Salts, Chlorophyll-a and Physicochemical Condition in El-Mex Bay Water, Alexandria, Egypt. American Journal of Biological and Environmental Statistics. Vol. 3, No. 4, 2017, pp. 54-64. doi: 10.11648/j.ajbes.20170304.13

Received: January 24, 2017; Accepted: February 17, 2017; Published: December 18, 2017

\begin{abstract}
The present work aimed to study the physicochemical parameters and nutrient salts of El Mex Bay area to evaluate its composition since El- Mex Bay exposed to several kinds of human activities and receive different types of industrial pollutants. Various pollutants are dumped daily by industrial, agricultural and domestic sources over Alexandria coasts through several outfalls, El-Mex Bay one of these disposal sites (El-Mex Pumping Station). Surface and bottom water samples were collected seasonally during the period from September (summer) 2012 to April (spring) 2013. Salinity variation appeared in water quality changes, it ranged from $2.25 \%$ to $38.87 \%$ and from $26.21 \%$ to $39.64 \%$ at the surface and bottom water, respectively. Dissolved oxygen levels indicated poor aeration conditions along the water column, it is lower in most stations at surface layer (ND-3.15 mgl $\left.{ }^{-1}\right)$ than that in the bottom layer $\left(0.79-6.28 \mathrm{mgl}^{-1}\right)$. The $\mathrm{pH}$ values of the study area at surface ranged (7.05 - 8.73), while at the bottom water ranged (7.18 - 8.45). Inorganic nitrogen species in El-Mex Bay water decreased in the order of $\mathrm{NH}_{4}{ }^{+}>\mathrm{NO}_{3}{ }^{-}>\mathrm{NO}_{2}{ }^{-}$. The measured nutrient content varied greatly as follows: $\mathrm{NH}_{4}{ }^{+}, 4.73 \pm 5.70$ to $99.27 \pm 72.53 \mu \mathrm{M} ; \mathrm{NO}_{2}^{-}, 0.72 \pm 0.43$ to $4.34 \pm 3.43 \mu \mathrm{M} ; \mathrm{NO}_{3}^{-}, 1.33 \pm 1.01$ to $31.68 \pm 24.59 \mu \mathrm{M}$ Regional and seasonal variations of total nitrogen concentration in El-Mex Bay surface and bottom water ranged from $28.26 \pm 14.87$ to $335.12 \pm 226.66 \mu \mathrm{M}$. The concentrations of reactive phosphate $\left(\mathrm{PO}_{4}\right)$ and total phosphorus (TP) were in the ranges of 0.05-17.36 $\mu \mathrm{M}$ and 0.11-28.01 $\mu \mathrm{M}$, respectively. As a result of nutrient enrichment, phytoplankton growth was very intensive, reflected by an abnormally high concentration of chlorophyll- $a$ (annual average: $13.64 \pm 10.69 \mu \mathrm{g} \mathrm{l}^{-1}$ at surface and $3.96 \pm 2.42 \mu \mathrm{g} \mathrm{l^{-1 }}$ at bottom water).
\end{abstract}

Keywords: Chlorophyll- $A$, Nutrient Salt, El Mex Bay, Salinity

\section{Introduction}

Ecosystems are complex and dynamic. This makes linking any one effect to a specific cause very difficult and conditions cannot be controlled [1]. One of the major environmental problems in Alexandria city is seawater pollutions. Various pollutants are dumped daily by industrial, agricultural and domestic sources over Alexandria coasts through several outfalls, El-Mex Bay one of these disposal sites (El-Mex Pumping Station). Water pollution is a serious problem in the ecosystem. It has been suggested that it is the leading worldwide cause of death and diseases. It accounts for the death of more than 14,000 people daily [2]. Estuaries and coastal areas have industrial activities because of the ease of transport. Moreover, the sea offers a convenient place for the disposal of waste substances. At least $40 \%$ of all marine contaminants come from land-based sources [3]. Urbanization imposes a physical and chemical load to surrounding water bodies, changing the ecosystem and leaving a record of disturbance in the sediments of the water body [4, 5]. The Mediterranean Sea is generally characterized by nutrient decrease from west to east resulting in variations in the structure of the pelagic food web [6, 7]. A primary reason for low nutrient concentrations is the anti-estuarine circulation of the Mediterranean Sea $[8,9]$. Nutrient acted as raw materials for the organism within the ecosystem to build up their cells and tissues and to continue their growth, but, without it the 
organism will not be able to survive. El-Mex Bay represents a shallow sheltered Estuary west of Alexandria. The discharges into the Bay caused the increase of nutrient levels in the coastal waters which consequently become Eutrophic. Eutrophication is a complex process which occurs both in fresh and marine waters, where excessive development of certain types of algae disturbs the aquatic ecosystems and becomes a threat for animal and human health. The primary cause of eutrophication is an excessive concentration of plant nutrients which cause phytoplankton to grow and may use up all the oxygen in the water, leaving none for other marine life [10]. An ecosystem is a closed system, where everything that it requires to activate the system comes within the system itself. The present work aimed to study the physicochemical parameters and nutrients salts of El Mex Bay water to evaluate its composition since El- Mex Bay exposed to several kinds of human activities and receive different types of industrial pollutants.

\section{Material and Methods}

\subsection{Study Area}

El-Mex Bay receives a heavy load of waste water $(2.6 \mathrm{x}$
$10^{9} \mathrm{~m}^{3} \mathrm{y}^{-1}$ ) both directly from industrial out falls and indirectly from Lake Mariut via El-Mex pumping station. The main outfalls are; Misr Chemical Industries, Mex pumping station on El-Umum drain, combined wastewater from Tanneries and slaughterhouse, El-Noubaria Canal and Mahmoudeya Canal [11]. El-Mex Bay is characterized by the presence of two water layers overlaying each other [12]. an upper brackish layer characterized by higher temperature and low salinity, and a lower seawater layer which has a properties similar to open Mediterranean with lower temperature and high salinity [13, 14]. Eight stations were selected to cover the whole area of EL-Mex Bay. The positions of these stations are shown in Figure 1. El-Mex area lies at the western part of Alexandria city. it is one of the main fishing grounds of Alexandria located between longitude from $29^{\circ} 48^{\prime} 20.44^{\prime \prime}$ to $29^{\circ} 51^{\prime} 0.00^{\prime \prime} \mathrm{E}$ and latitude from $31^{\circ} 8^{\prime} 34.188^{\prime \prime}$ to $31^{\circ} 10^{\prime} 29.85^{\prime \prime} \mathrm{N}$. it represent a shallow sheltered Estuary west of Alexandria, extends for about 15 $\mathrm{km}$ between El-Agamy headland to the west to the Western harbor to the east and from the coast to a depth of about 30 $\mathrm{m}$. The Bay has a mean depth of $10 \mathrm{~m}$. Its surface area is about $19.4 \mathrm{~km}^{2}$ and its volume $190.3 \times 10^{6} \mathrm{~m}^{3}$ [15].

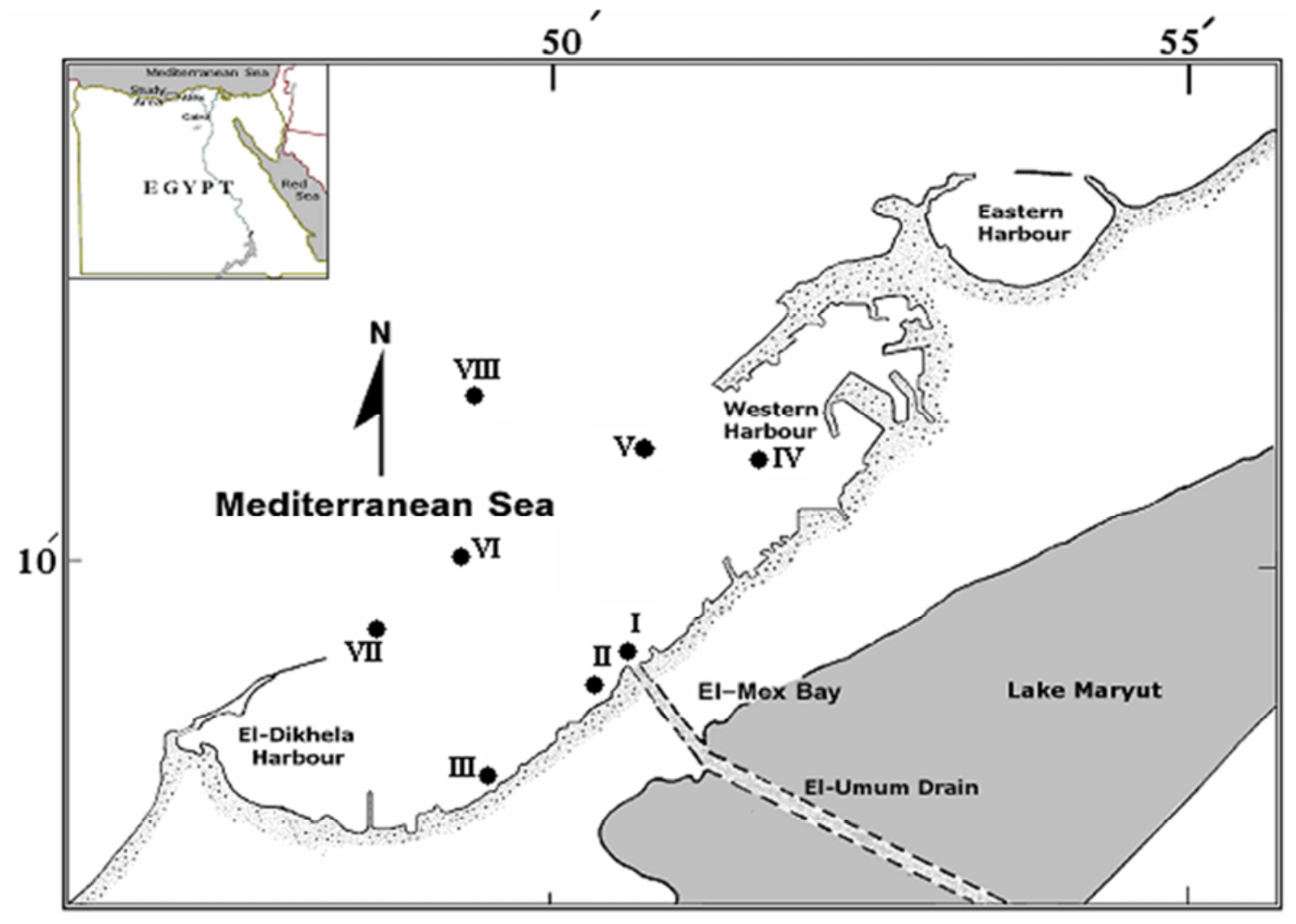

Figure 1. Sampling Stations.

\subsection{Sampling and Analysis}

Surface and bottom water samples were collected seasonally during the period from September (summer) 2012 to April (spring) 2013. Temperatures were measured in-situ using thermometer. The $\mathrm{pH}$ value was measured using $\mathrm{pH}$ - meter (JENWAY, 3505 Electrochemistry Analyzer pHmeter). Salinity was determined using a salinometer (model, YSI556MPS). The classical Winkler method, modified by Grasshoff (1983) [16] was used for determination of dissolved oxygen (DO). The method used for the determination of oxidizable organic matter (OOM) was 
described by FAO. (1976) [17]. Chlorophyll-a was measured according to the method described by Strickland and Parsons (1972) [18] using a spectrophotometer (Shimadzu UV-15002). The total nitrogen (TN) and total phosphorus (TP) were determined in unfiltered seawater samples [19], while it was filtered before analyzing $\mathrm{PO}_{4}-\mathrm{P}, \mathrm{NO}_{2}-\mathrm{N}, \mathrm{NO}_{3}-\mathrm{N}$ and $\mathrm{SiO}_{4}-\mathrm{Si}$ and kept under deep freeze until their analysis in the laboratory spectrophotometrically using a spectrophotometer (Shimadzu UV-150-02). Ammonium $\left(\mathrm{NH}_{4}-\mathrm{N}\right)$ was determined, using the indophenols blue technique described by IOC (1983) [20]. The determination of nitrite, nitrate, phosphate and silicate were described by Grasshff (1983) [16].

\subsection{Statistical Analysis}

The statistical analysis was performed which included correlation matrices between the different investigated variables and testing the significance of a relation between different variables. Different computer programs were used in this work: Excel 2007, Word 2007, Surfer 9 and SPSS 18.

\section{Results and Discussions}

\subsection{Physicochemical Parameters of El-Mex Bay Water}

\subsubsection{Temperature}

Water temperature plays an important role in a variety of biological processes. The temperature affects the growth, survival, distribution and the rate of oxygen consumption by aquatic environment. In the present study, seasonal and regional variations of temperature in the period from autumn 2012 to spring 2013 gave significant changes in surface and bottom temperature values. The temperature of bottom water in El-Mex Bay is lower than that recorded in surface water. In the summer period, the temperature was high, with an average $26.74^{\circ} \mathrm{C}$ and the smallest temperature in winter with an average $17.36^{\circ} \mathrm{C}$ (Table 1). The temperature value in all seasons except in spring increased in the direction of the north-west at El-Mex Bay.

\subsubsection{PH Value}

The $\mathrm{pH}$ value is the master control parameter in the aquatic environment for the chemical and biological system of water. It is an important water quality indicator, in the aquatic environment; the hydrogen ion plays an important role in many life processes where the living organisms are dependent and sensitive. The recorded $\mathrm{pH}$ value in El-Mex Bay was always in the alkaline side, values of both surface and bottom water varied within narrow limits (Table 1). The $\mathrm{pH}$ values in El-Mex Bay in summer, autumn, winter and spring ranged from 7.05 to $7.71,7.60$ to $8.25,7.60$ to 8.34 and 7.49 to 8.73 , respectively. The $\mathrm{pH}$ values of El-Mex Bay at surface ranged from 7.05 in summer 2012 to 8.73 in spring 2013, while at the bottom water ranged from 7.18 in summer 2012 to 8.45 in spring 2013. The slightly high surface $\mathrm{pH}$ values are mainly related to the increase in photosynthetic activity in the surface

\subsubsection{Salinity (\%o)}

It is a measure of the salt content of seawater and is equivalent to the total amount of dissolved solids in seawater by weight. Salinity in El-Mex Bay water varied regionally within a wide range, from Mediterranean seawater in the north to brackish water near El-Umum Drain outlet. The surface salinity water ranged from $2.25 \%$ in winter 2013 to $38.87 \%$ in summer 2012 , while at the bottom water ranged from $26.21 \%$ in autumn 2012 to $39.64 \%$ in summer 2012 (Table 1). The salinity increased at the bottom water comparing with those recorded at the surface, this related to the presence of mixing with fresh water [21]. The water in front of El-Umum Drain is characterized by low salinity (brackish water) ranged between 2.25 and 32.00, depends primarily on the amount of brackish water discharged through the drain. It's clear from the horizontal distribution of salinity at different seasons of El-Mex Bay was characterized by the presence of two water layers overlying each other upper brackish layer and lower diluted seawater. At surface water, a significant variation of salinity was observed due to discharge of outfalls from El-Umum drain. At bottom water, a small variation of salinity was observed.

\subsubsection{Dissolved Oxygen (DO)}

Dissolved oxygen (DO) is the amount of oxygen in seawater. Without oxygen, aquatic system could not support life. All organisms in seawater need oxygen for respiration. During respiration, organisms consume oxygen and give off carbon dioxide. Dissolved oxygen content in the surface water can tell us about photosynthesis and the air- sea exchange. DO in the surface and bottom water of El-Mex Bay during the period of investigation is shown in Table1. The amount of dissolved oxygen in surface water in El-Mex Bay ranged from ND in summer 2012 to $3.15 \mathrm{mgl}^{-1}$ in spring 2013, for bottom water ranged from $0.79 \mathrm{mgl}^{-1}$ in summer 2012 to $6.28 \mathrm{mgl}^{-1}$ in winter 2013. DO in El-Mex Bay water is lower in most stations at surface layer than that in the bottom layer. The average values of DO increased in winter and spring. In front of El-Umum drain water was characterized by low oxygen content may be due to biological oxygen demand [22]. The dissolved oxygen in winter is slightly higher due to the water turbulent and mixing processes which lead to increase the dissolution of the atmospheric oxygen.

\subsubsection{Oxidizable Organic Matter (OOM)}

Oxidizable organic matter has been used as basic water quality parameter to assess organic pollution, adversely affecting aquatic life, principally through oxygen depletion. Organic matter plays a major role in aquatic systems. It affects biogeochemical process, nutrient cycling, biological availability, and chemical transport and interaction. Duursma (1961) [23] showed that, dissolved organic substances might be attributed to the decomposition of dead phytoplankton and detritus rather than excretion from living cells. Prosi and Lierde (1983) [24] pointed out that, the organic matter in the aquatic systems consists of the remains of biologically produced sources and the synthetic organic substances 
originate from agricultural and industrial applications. Seasonal and regional variation of OOM at El-Mex Bay are illustrated in Table 1, where the minimum is $0.48 \mathrm{mgO}_{2} \mathrm{l}^{-1}$ in autumn 2012 and maximum is $16.00 \mathrm{mgO}_{2} \mathrm{l}^{-1}$ in winter 2013 . In the four seasons, the OOM in surface is higher than that in bottom except in autumn 2012 in station VI and winter 2013 at station IV. High values of oxidizable organic matter indicated that water pollution was present, which was linked to sewage effluents discharged into the area, it was appeared at station I and II. The seasonal variation of OOM presented abrupt fluctuations during the year due to the external manipulation of the bay. The average of OOM in El-Mex bay water ranged between minimum $\left(1.44 \mathrm{mgO}_{2} \mathrm{l}^{-1}\right)$ in winter and maximum $\left(9.95 \mathrm{mgO}_{2} \mathrm{l}^{-1}\right)$ in spring. The results showed that the distribution in summer surface water increased towards north and east directions, while in bottom water showed increasing toward eastern south. In autumn 2012, the OOM in surface and bottom water increased toward south direction. In winter 2013, the OOM in surface and bottom water increased from western south toward eastern north direction. In spring 2013, the OOM in surface and bottom increased from western south toward eastern north direction.

Table 1. Min. Max. and Average of Physicochemical Parameters in El Mex Bay Water during 2012-2013.

\begin{tabular}{|c|c|c|c|c|c|c|c|c|c|}
\hline & & \multirow{2}{*}{$\begin{array}{l}\text { Summer } \\
2012 \\
\end{array}$} & & \multicolumn{2}{|c|}{ Autumn } & \multirow{2}{*}{$\begin{array}{l}\text { Winter } \\
2013 \\
\end{array}$} & \multicolumn{2}{|c|}{ Spring } & \multirow[b]{3}{*}{ B } \\
\hline & & & & & & & & & \\
\hline & & $\mathbf{S}$ & B & $\mathbf{S}$ & B & $\mathbf{S}$ & B & $\mathbf{S}$ & \\
\hline \multirow[t]{3}{*}{ Temp. $\left({ }^{\circ} \mathrm{C}\right)$} & Min. & 24.00 & 23.50 & 16.20 & 16.00 & 16.05 & 17.30 & 19.20 & 19.06 \\
\hline & Max. & 29.00 & 27.00 & 19.00 & 18.95 & 18.05 & 17.49 & 19.97 & 19.41 \\
\hline & Ave. & 26.5 & 25.25 & 17.6 & 17.48 & 17.05 & 17.40 & 19.59 & 19.24 \\
\hline \multirow[t]{2}{*}{$\mathrm{pH}$} & Min. & 7.05 & 7.53 & 7.60 & 7.72 & 7.60 & 8.22 & 7.49 & 8.24 \\
\hline & Max. & 7.71 & 7.69 & 8.08 & 8.25 & 8.26 & 8.34 & 8.73 & 8.45 \\
\hline \multirow{2}{*}{ Salinity } & Max. & 38.87 & 39.64 & 36.19 & 37.72 & 38.40 & 38.56 & 37.87 & 38.64 \\
\hline & Ave. & 32.86 & 37.01 & 28.72 & 36.36 & 28.03 & 38.40 & 28.28 & 38.01 \\
\hline \multirow[t]{3}{*}{$\mathrm{DO}\left(\mathrm{mgl}^{-1}\right)$} & Min. & 0.00 & 0.79 & 0.41 & 1.38 & 0.29 & 2.85 & 0.00 & 1.36 \\
\hline & Max. & 0.82 & 1.41 & 1.96 & 2.00 & 2.84 & 3.37 & 3.15 & 6.28 \\
\hline & Ave. & 0.57 & 1.03 & 1.33 & 1.78 & 1.76 & 3.16 & 1.56 & 3.31 \\
\hline \multirow[t]{2}{*}{$\mathrm{OOM}\left(\mathrm{mgO}_{2}{ }^{\mathrm{l}} 1\right)$} & Min. & 2.40 & 0.64 & 0.48 & 0.64 & 1.60 & 0.64 & 3.52 & 1.60 \\
\hline & Max. & 14.40 & 2.56 & 15.20 & 7.52 & 16.00 & 1.92 & 15.52 & 7.52 \\
\hline
\end{tabular}

\subsection{Inorganic Nitrogen Species}

Although molecular nitrogen is the most abundant gas in the atmosphere, plants cannot use nitrogen in this form, as they need it in the form of $\mathrm{NH}_{4}^{+}, \mathrm{NO}_{2}{ }^{-}$and $\mathrm{NO}_{3}{ }^{-}$. Nitrogen fixing bacteria have the ability to fix nitrogen by combining it with hydrogen to make $\mathrm{NH}_{4}{ }^{+}$. On the other hand, $\mathrm{NO}_{2}{ }^{-}$ forming bacteria combine nitrogen with oxygen forming $\mathrm{NO}_{2}{ }^{-}$while the $\mathrm{NO}_{3}{ }^{-}$forming bacteria convert $\mathrm{NO}_{2}{ }^{-}$to $\mathrm{NO}_{3}{ }^{-}$. In these inorganic forms, nitrogen can be absorbed and used by green plants.

\subsubsection{Ammonium $\left(\mathrm{NH}_{4}-\mathrm{N}\right)$}

Ammonium is presented naturally in surface and wastewaters. It is a critical compound in the nitrogen cycle of the sea. It is an important and often the primary source of nitrogen for the phytoplankton of oligo- trophic regions. Its concentration generally is low in ground waters because it adsorbs to soil particles and clays and is not leached readily from soils. It is produced largely by deamination of organic nitrogen-containing compounds and by hydrolysis of urea. At some water treatment plants ammonia is added to react with chlorine to form combined chlorine residual. Ammonia concentrations encountered in water vary from less than $0.714 \mu \mathrm{M} \mathrm{NH}_{4}-\mathrm{N}$ in some natural surface and ground waters to more than $2142.85 \mu \mathrm{M}$ in some wastewaters. However, the increase in the concentration of ammonia $\left(\mathrm{NH}_{3}\right)$ leads to toxic and death for fishes and other aquatic organisms but ammonium ion $\left(\mathrm{NH}_{4}{ }^{+}\right)$has no effect on aquatic organisms or fishes [25]. Generally, ammonia toxicity causes osmoregularity imbalance, kidney failure, and suppressed excretion of endogenous ammonia, resulting in neurological or cytological failure and damage to the gill epithelium leading to suffocation. Various factors affect ammonia toxicity, including urea, amine, amine oxide derivatives, creatine, creatinine, uric acid, carbon dioxide and dissolved oxygen concentrations [26]. Ammonium nitrogen exists in aqueous solution either as ammonium ion $\left(\mathrm{NH}_{4}{ }^{+}\right)$or as ammonia $\left(\mathrm{NH}_{3}\right)$ depending on the $\mathrm{pH}$ of the solution, in accordance with the following equilibrium reaction:

\section{$\mathrm{NH}_{3}+\mathrm{H}_{2} \mathrm{O} \rightleftarrows \mathrm{NH}_{4}^{+}+\mathrm{OH}^{-}$}

At $\mathrm{pH}$ above 7, the equilibrium is displaced to the left. At $\mathrm{pH}<7 \mathrm{NH}_{4}^{+}$is predominant.

In the present study, increase in ammonium content is observed at El-Mex pumping station at station I. Concentration of ammonium in bottom water is lower than that in surface water except at station III in summer 2012 and station IV in spring 2013. In surface water $\mathrm{NH}_{4}-\mathrm{N}$ concentration ranged from $4.18 \mu \mathrm{M}$ in spring 2013 to 219.13 $\mu \mathrm{M}$ in winter 2013 and in bottom water ranged from $1.25 \mu \mathrm{M}$ in winter 2013 to $110.00 \mu \mathrm{M}$ in autumn 2012 ( Table 2 and Figure 2). Ammonium concentration attended a minimum and a maximum value during winter being to $1.25 \mu \mathrm{M}$ and $219.13 \mu \mathrm{M}$, respectively, with an average of $42.72 \mu \mathrm{M}$. It is declare obviously that the increasing levels of $\mathrm{NH}_{4}{ }^{+} \mathrm{N}$ in the Bay water could be accompanied with the ammonification 
process and decomposition of organic matter yielding ammonium by heterotrophic bacterial action [27]. The ammonium and bicarbonate are the final products from bacterial decomposition of organic matter as reported by Weimer and Lee, (1973) [28].

Horizontal distribution of $\mathrm{NH}_{4}-\mathrm{N}$ is given in Figure 2; it showed high variations in ammonium content through the seasons. In summer 2012 period, the ammonium concentration increased from El-Umum drain to western south direction in surface water and from station VII to eastern north at bottom water from eastern south to western north. In autumn 2012 and summer 2013 period, at surface and bottom water it increased from western north to near ElUmum drain. In winter 2013 period, NH4-N concentration decreased from El-Umum drain to station III at surface water and from station VII to the north at bottom water increased from north to station III.

\subsubsection{Nitrite $\left(\mathrm{NO}_{2}-\mathrm{N}\right)$}

It appears in the water mainly as a result of biochemical oxidation of ammonia (nitrification) or the reduction of nitrate (denitrification). Nitrite is an intermediate oxidation state of nitrogen, both in the oxidation of ammonia to nitrate and in the reduction of nitrate. Such oxidation and reduction may occur in wastewater treatment plants, water distribution systems, and natural waters. Nitrite can enter a water supply system through its use as a corrosion inhibitor in industrial process water [29].

The concentrations of $\mathrm{NO}_{2}-\mathrm{N}$ at El-Mex Bay water showed considerable seasonal and regional variations (Table 2 and Figure 3), its concentration ranged from 0.02 to $4.05 \mu \mathrm{M}$, ranged from 0.25 to $9.49 \mu \mathrm{M}$, ranged from 0.12 to $10.02 \mu \mathrm{M}$ and ranged from 0.10 to $3.56 \mu \mathrm{M}$ in summer, autumn, winter and spring, respectively, with an average value ranged between $0.10 \mu \mathrm{M}$ in spring and $10.02 \mu \mathrm{M}$ in winter at surface water and ranged from $0.02 \mu \mathrm{M}$ in summer to $4.56 \mu \mathrm{M}$ in autumn at bottom water (Figure 3). The data showed decrease in the nitrite content in the summer and spring at ElMex Bay water might be due to the increase in the oxidation rate of nitrite to nitrate. As a result of biological denitrification of nitrite which converts it into cellular amino acids via the photosynthetic process and by transaminase enzyme which ultimately provide the fats, fatty acids, amino acids, nucleic acids, protein, organic acids and other organic compounds necessary for growth and reproduction of these organisms [30].

The horizontal distribution of $\mathrm{NO}_{2}-\mathrm{N}$ is represented in Figure 3, the results showed high variations in nitrite concentration through the seasons. In summer period surface water 2012, nitrite concentration increased from El-Umum drain to western south direction and from station VII to eastern north, at the same period $\mathrm{NO}_{2}-\mathrm{N}$ content at the bottom water increased to El-Dekilah Head. In autumn period 2012, at surface water, $\mathrm{NO}_{2}-\mathrm{N}$ cntent decreased from station III to north and at bottom water it decreased from station III to V. In winter period 2013, at surface water it decreased from El-Umum drain to station III and from station
VII to the north and at bottom water increased from north to station III. In spring period 2013, at surface water it decreased from station III to station VI and at bottom water from station III to the north.
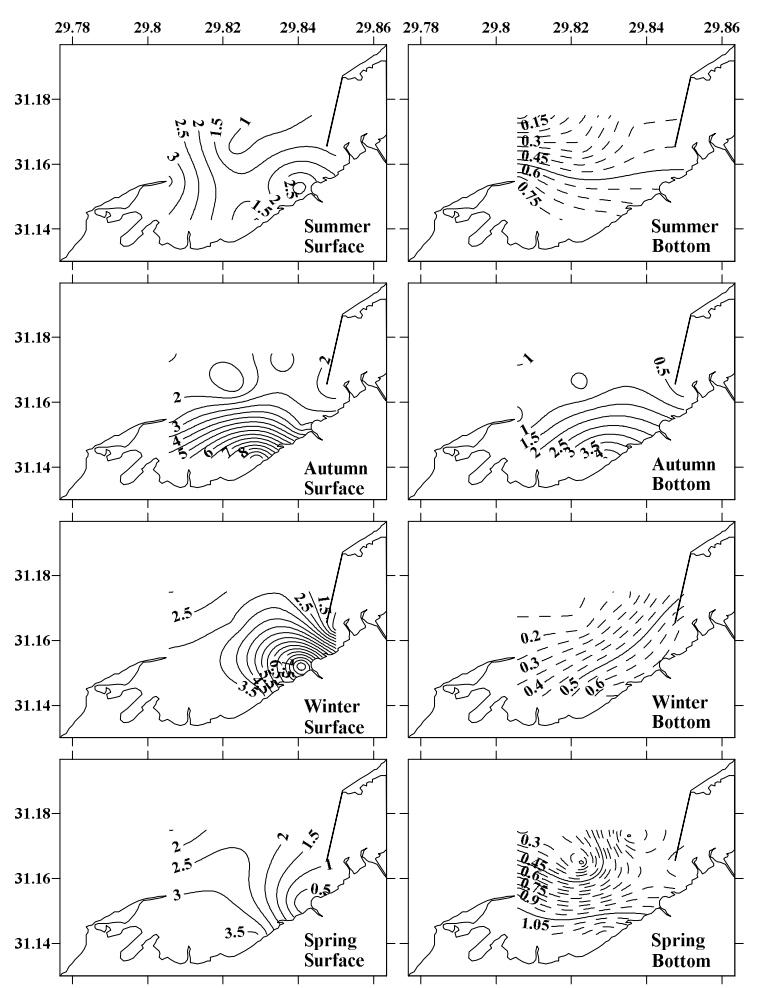

Figure 2. Horizontal distribution of $\mathrm{NH}_{4}-\mathrm{N}$ concentration $(\mu \mathrm{M})$ in surface and bottom water, El-Mex Bay during 2012-2013.

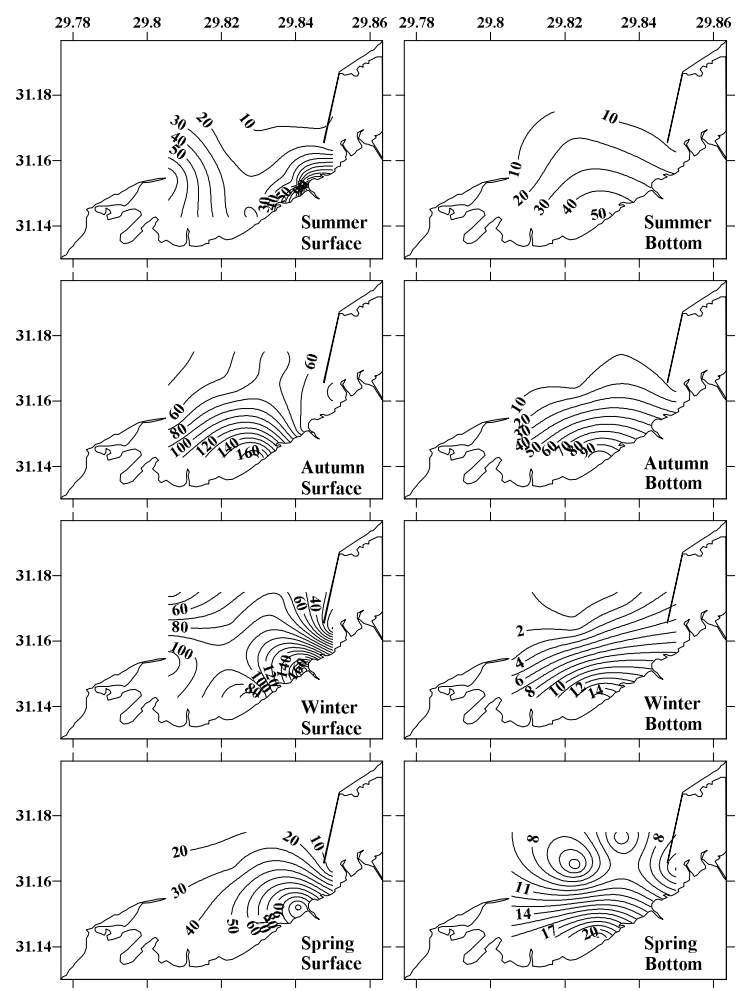

Figure 3. Horizontal distribution of $\mathrm{NO}_{2}-\mathrm{N}$ concentration $(\mu \mathrm{M})$ in surface and bottom water, El-Mex Bay during 2012-2013. 


\subsubsection{Nitrate $\left(\mathrm{NO}_{3}-\mathrm{N}\right)$}

The major nitrogenous compound in the aquatic environment is nitrate. The behavior of nitrate is important in the nitrogen metabolism in natural water [31]. Its behavior may be attributed to the biological, chemical or physical factors. It is the most stable form of inorganic nitrogen in oxygenated water. Nitrate is considered to be the only stable oxidation level in the presence of oxygen in water. In an aerobic condition in the aquatic environment nitrification takes place converting ammonia and nitrite to nitrate. In the present study, concentrations of nitrate in El-Mex Bay water are shown in Table 2 and Figure 4, which ranged from 0.10 to $3.01 \mu \mathrm{M}$, ranged from 3.71 to $9.10 \mu \mathrm{M}$, ranged from 0.82 to $11.02 \mu \mathrm{M}$ and ranged from 0.05 to $2.80 \mu \mathrm{M}$ in summer, autumn, winter and spring, respectively. The average concentration of nitrate in El-Mex bay water fluctuated between $0.05 \mu \mathrm{M}$ in spring and $66.70 \mu \mathrm{M}$ in winter at surface water and from $0.10 \mu \mathrm{M}$ in summer period to $11.02 \mu \mathrm{M}$ in winter period at bottom water (Figure 4). This data showed that the concentration of $\mathrm{NO}_{3}-\mathrm{N}$ in surface water is higher than those recorded in bottom water in winter and spring periods.

Consumption of nitrate compounds by phytoplanktone in the study area can be considered as the main reason for decreasing nitrate concentrations in the Bay water. The high concentrations of nitrate in the study area may be due to large quantities of nitrate fertilizers and organic matter. Horizontal distribution of $\mathrm{NO}_{3}-\mathrm{N}$ is represented in Figure 4. In summer 2012, nitrate concentration at surface water decreased from western north (station III) to north near El-Umum drain, while in bottom water, showed slightly variations in nitrate concentration. In autumn 2012, nitrate content decreased from station III to north and in bottom water, it decreased from station V to the center of El-Mex Bay. In winter 2013, at surface water, it increased from El-Umum drain to station III and at the bottom; it increased from VIII to the north. In spring 2013, slightly variation in nitrate concentration at surface and bottom water increased from El-Umum drain to western north at the surface and from west to east.

\subsection{Total Nitrogen (TN)}

Total nitrogen is an essential nutrient for plants and animals. However, an excess amount of nitrogen in a waterway may lead to low levels of dissolved oxygen and negatively alter various plant life and organisms. Sources of nitrogen include: wastewater treatment plants, runoff from fertilized lawns and croplands, failing septic systems, runoff from animal manure and storage areas, and industrial discharges that contain corrosion inhibitors. Total nitrogen, composed of organic nitrogen (including some aromatic nitrogen-containing compounds), ammonia, nitrite, and nitrate. Molecular nitrogen is not determined and recovery of some industrial nitrogen-containing compounds is low [32]. In the present study, the concentrations of $\mathrm{TN}$ are illustrated in Table 2 and Figure 5. The amount of TN in El-Mex Bay ranged from 12.29 to $212.72 \mu \mathrm{M}$ in summer period, from 20.67 to $255.65 \mu \mathrm{M}$ in autumn, from 27.50 to $812.71 \mu \mathrm{M}$ in winter and from 19.04 to $334.65 \mu \mathrm{M}$ in spring. The average content of TN in El-Mex Bay water is flocculated between 99.27 to $335.12 \mu \mathrm{M}$ in surface water and 35.77 to $76.51 \mu \mathrm{M}$ in bottom water (Figure 5). From this data observed that the concentration of TN in surface water is higher than those recorded in bottom water, this may be attributed to the high content of both dissolved organic nitrogen and particulate nitrogen [33]. The horizontal distribution of $\mathrm{TN}$ is represented in Figure 5. In summer 2012 and winter 2013 at surface water, the data showed decreased from El-Umum drain to station III and from station VII to eastern north. At bottom water in summer, the $\mathrm{TN}$ content showed slightly variations which increased toward the center of El-Mex Bay. In the autumn 2012, at surface and bottom waters showed the same trend increasing toward the western south. In winter 2013, at bottom water showed increased from north to south. In spring 2013, it showed increasing toward eastern south in surface water and slightly variation in the bottom water.
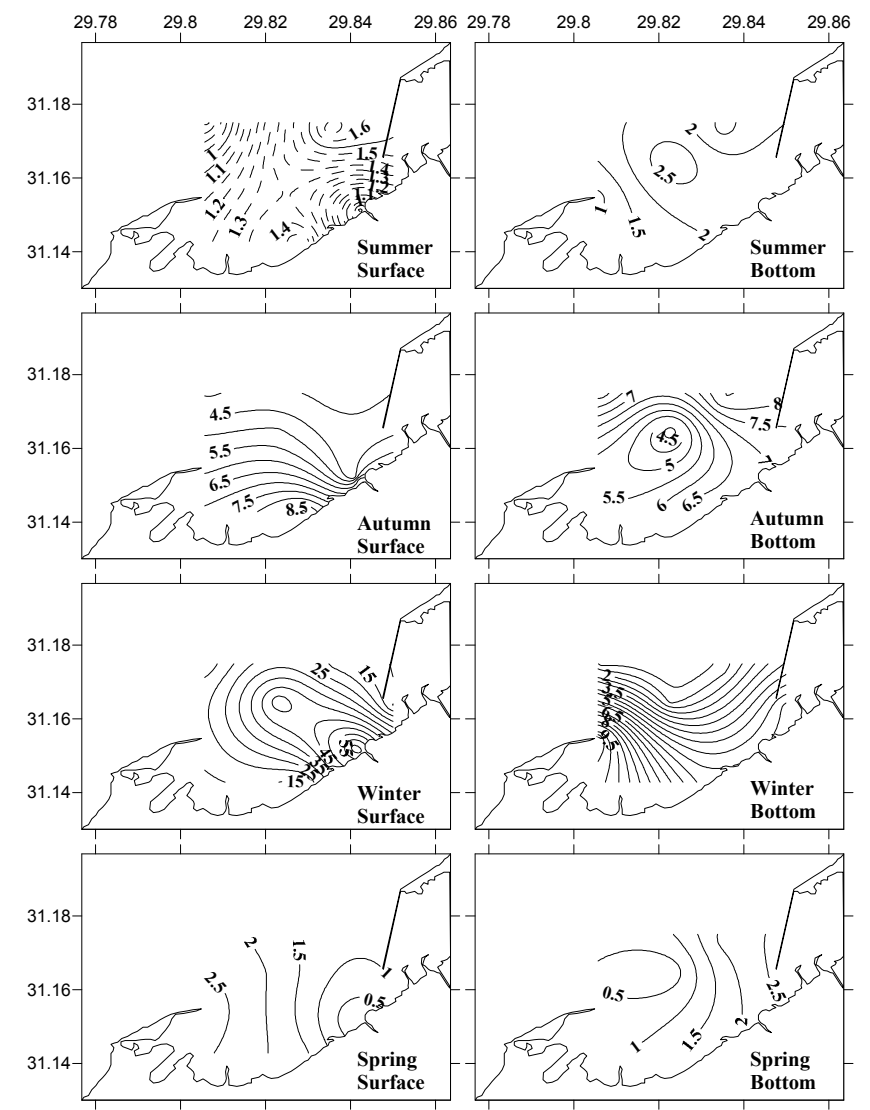

Figure 4. Horizontal distribution of $\mathrm{NO}_{3}-\mathrm{N}$ concentration $(\mu \mathrm{M})$ in surface and bottom water, El-Mex Bay during 2012-2013.

\subsection{Reactive Phosphate $\left(\mathrm{PO}_{4}-\mathrm{P}\right)$}

Phosphorus occurs in natural waters and in wastewaters only about as phosphates. These are classified as orthophosphates, condensed phosphates, and organically bound phosphates. They occur in solution, in particles or detritus, or in the bodies of aquatic organisms. These forms of phosphate arise from a variety of sources. Small amounts of orthophosphate or certain condensed phosphates are added to some water supplies during treatment. Larger quantities of 
the same compounds may be added when the water is used for laundering or other cleaning, because these materials are major constituents of many commercial cleaning preparations. Phosphates are used extensively in the treatment of boiler waters. Orthophosphates applied to agricultural or residential cultivated land as fertilizers are carried into surface waters with storm runoff and to a lesser extent with melting snow. Organic phosphates are formed primarily by biological processes. They are contributed to sewage by body wastes and food residues, and also may be formed from orthophosphates in biological treatment processes or by receiving water biota. Phosphorus is essential to the growth of organisms and can be the nutrient that limits the primary productivity of a body of water. In instances where phosphate is a growth-limiting nutrient, the discharge of raw or treated wastewater, agricultural drainage, or certain industrial wastes to that water may stimulate the growth of photosynthetic aquatic micro- and macro organisms in nuisance quantities $[11,34]$.
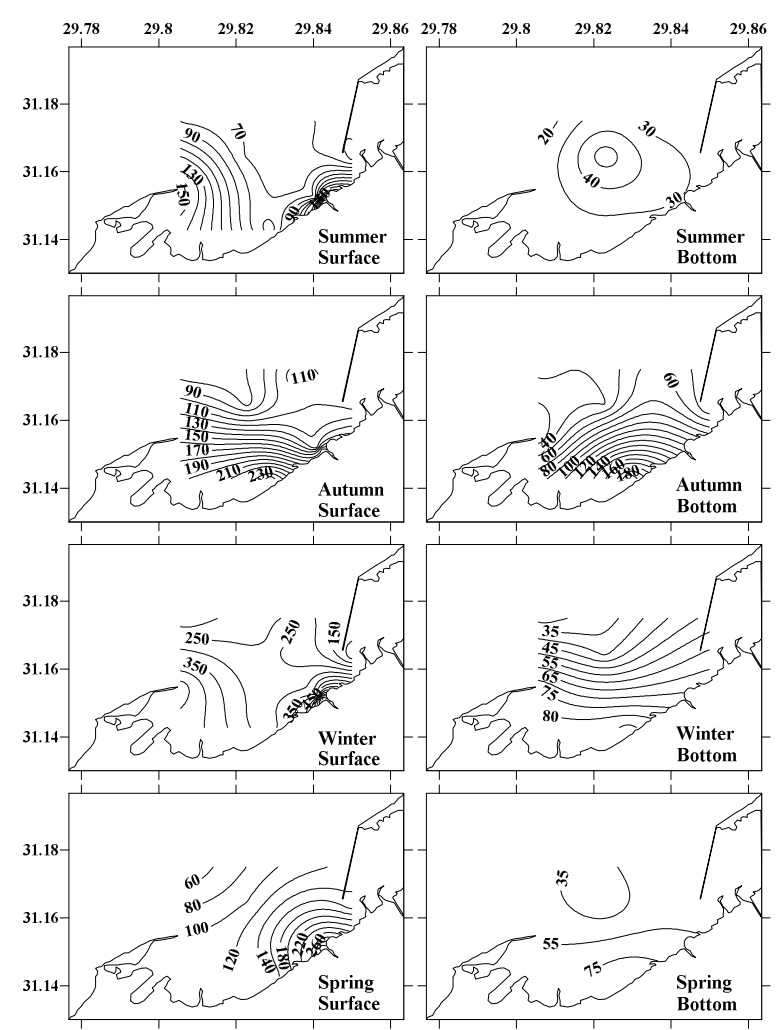

Figure 5. Horizontal distribution of TN concentration $(\mu M)$ in surface and bottom water, El-Mex Bay during 2012- 2013.

Table 2 and Figure 6, showed the variation of phosphate concentration in El-Mex Bay water during 2012-2013. The data given indicated that spatial concentrations of phosphate were fluctuated between $0.05 \mu \mathrm{M}$ in station VIII at bottom water in spring 2013 and $17.36 \mu \mathrm{M}$ at surface water in station $\mathrm{I}$ in winter 2013. The regional average content of $\mathrm{PO}_{4}-\mathrm{P}$ ranged between $0.25 \mu \mathrm{M}$ at bottom water in spring and 7.02 $\mu \mathrm{M}$ at surface water in winter. Phosphate concentration in brackish water (station I) in surface water was $4.80 \mu \mathrm{M}$ in summer period, decreased to $4.59 \mu \mathrm{M}$ in autumn followed by increasing to $7.02 \mu \mathrm{M}$ in winter and decrease again $2.13 \mu \mathrm{M}$ in spring, In bottom water the concentration of phosphate was $1.12 \mu \mathrm{M}$ in summer, increased to $2.22 \mu \mathrm{M}$ in autumn followed by decreasing in winter $0.92 \mu \mathrm{M}$ and spring $0.24 \mu \mathrm{M}$ (Figure 6). Seasonal variations of $\mathrm{PO}_{4}-\mathrm{P}$ concentrations in the study area were widely varied in the different seasons, which in bottom water are lower than that at surface water; this could be associated with the biological uptake and/or additional phosphate sources.

The increasing of reactive phosphate concentration is due to run off of waste waters. The horizontal distribution of $\mathrm{PO}_{4}$ $\mathrm{P}$ (Figure 6), It showed high variation in RP concentration at El-Mex Bay. In summer 2012, surface water of $\mathrm{PO}_{4}-\mathrm{P}$ content decreased toward the western north direction and at bottom water it decreased from station VII to the eastern north. In the surface and bottom water during autumn 2012, the data showed decreasing from station III to the western north. In winter 2013, at surface water it is showed decreasing from El-Umum drain to station III and increasing from north to station VII, and at bottom water decreasing from west to east. In spring 2013, surface water showed increasing from western north to in front of El-Umum drain and at bottom water from station III to the north.

\subsection{Total Phosphorus (TP)}

Phosphorus compounds play a key role in photosynthesis and other processes in plants. It is taken by phytoplankton and enters the food chain in the sea. After depth and decomposition of organisms and plants, as portion of those phosphorus is returned to the water. Some species of phytoplankton are able to utilize dissolved organic phosphate. Distribution of different forms of phosphorus in seawater is broadly controlled by biological and physical agencies [35].

The amount of TP in El-Mex Bay water illustrated in Table 2 and Figure 7, which varied from 0.41 to $20.69 \mu \mathrm{M}$ in summer period, from 0.40 to $28.01 \mu \mathrm{M}$ in Autumn, from 0.11 to $24.11 \mu \mathrm{M}$ in winter and from 0.39 to $13.58 \mu \mathrm{M}$ in spring. In El-Mex Bay water the amount of TP deceased with depth except in station V at summer, station VI at autumn, station IV at winter, station IV and VIII in spring, this may be attributed to uptake of reactive phosphorus and increased in suspended matter and consequently adsorption and desorption processes influenced by the prevailing environmental conditions [36]. The average concentration of $\mathrm{TP}$ in El-Mex Bay in surface and bottom water ranged between 0.63 and $9.78 \mu \mathrm{M}$ (Figure 7). There is a small variation in TP concentration at El-Mex Bay water (Figure 7). In summer period, the TP content in surface water decreased toward the western north and slight difference in the bottom water.

In autumn period, surface water showed increasing from the center of El-Mex Bay toward the El-Umum drain and decreased from station III to the north in the bottom water. In winter season, the data showed high variations in surface water and a slight difference in the bottom. In spring, the data showed decreasing from El-Umum drain to the north in 
surface water and toward the center of El-Mex Bay in the bottom water.

\subsection{Reactive Silicate $\left(\mathrm{SiO}_{4}\right.$-Si)}

Silica is a naturally occurring compound that can be found in many forms such as sand, quartz, opal, rock, and sea floor sediments. It also is an important element in animal and plant life. Specifically biogenic silica is extracted from water by plants, microorganisms, or invertebrates for building structural materials and growth. Silicate is one of the important parameters which control marine productivity. Silicon is usually as silica $\left(\mathrm{SiO}_{2}\right)$ or silicates $\left(\mathrm{SiO}_{4}{ }^{-}\right.$and $\left.\mathrm{SiO}_{3}{ }^{2-}\right)$. Silicate is a good indicator of freshwater dispersion and potential for diatom blooms and exists in river water in three principal forms; dissolved silicon, aluminosilicate weathering products and detritus quartz. Dissolved silicon in river waters derived from the incongruent weathering of silicate and aluminosilicate rocks at the earth surface. It is a non-metallic element present in cell wall of diatoms. These diatoms are important phytoplankton group with regard to the primary productivity and natural food for some fish species. When diatoms are eaten, the remains sinks, then the silica dissolves slowly in water [11]. In the present study, concentrations of silicate at El-Mex Bay are shown in Table 2 and Figure 8, supported that the concentration of silicate in summer ranged from 7.28 to $193.71 \mu \mathrm{M}$, in autumn ranged from 10.51 to $213.09 \mu \mathrm{M}$, in winter ranged from 0.31 to 70.72 $\mu \mathrm{M}$ and in spring ranged from 0.37 to $125.32 \mu \mathrm{M}$. The average concentration of silicate in El-Mex Bay water fluctuated between $31.67 \mu \mathrm{M}$ in winter and $78.92 \mu \mathrm{M}$ in autumn at surface water and $2.15 \mu \mathrm{M}$ in winter to $37.12 \mu \mathrm{M}$ in autumn at bottom water, the results revealed that the concentration of silicate in surface water is higher than that in bottom water (Figure 8). There is an increase in silicate concentrations in summer and autumn due to decrease in the activity of diatoms, and other microorganisms [37]. On the other side, during winter and spring the lower Silicate concentrations may be due to the uptake by diatoms, bacteria and fishes [38]. Seasonal variations of silicate at El-Mex Bay water were observed during the period of study, which could be attributed to changes in sewage, agricultural and industrial effluents of El-Umum Drain.

Horizontal distribution of silicate is represented in Figure 8. In summer 2012, the data showed decreased from El-Umum drain to station III and from west to east in the surface and decreased from station VII to the north in the bottom. In the autumn 2012, the silicate concentration at surface and bottom decreased from station III to the north. In winter 2013, it increased from station III to El-Umum drain at surface water and decreased from western south to the north at bottom water. In spring 2013, at surface shows high variation in silicate content with increased toward El-Umum drain direction and decreased toward the north direction at bottom water.

\subsection{Chlorophyll-A (Chl-a)}

Chl-a concentration in the present study are shown in Table 2 and Figure 9. The levels of Chl-a in El-Mex Bay water showed wide variations, ranged from 0.19 to $9.62 \mu \mathrm{gl}^{-1}$ in summer, ranged from 0.52 to $14.72 \mu \mathrm{gl}^{-1}$ in autumn, ranged from 0.52 to $30.92 \mu \mathrm{gl}^{-1}$ in winter and ranged from 1.03 to $144.43 \mu \mathrm{gl}^{-1}$ in spring. The average values of the Chla in El-Mex Bay surface water were fluctuated between 4.71 $\mu \mathrm{gl}^{-1}$ in Summer to $37.55 \mu \mathrm{gl}^{-1}$ in spring and between 1.04 $\mu \mathrm{gl}^{-1}$ in winter and $11.59 \mu \mathrm{gl}^{-1}$ in spring at bottom water (Figure. 9). The concentrations of Chl-a in El-Mex Bay in some surface water was higher than that in bottom water, and showed high average concentration in spring 2013, this may be due to the algal bloom [39]. As regards the spatial distribution of Chl-a, the results showed that station IV had the highest concentration

Table 2. Min. Max. and Average of Nutrient Salts and Chlorophyll-a Content in El Mex Bay Water during 2012-2013.

\begin{tabular}{|c|c|c|c|c|c|c|c|c|c|}
\hline & & \multirow{2}{*}{$\begin{array}{l}\text { Summer } \\
2012\end{array}$} & \multicolumn{3}{|c|}{ Autumn } & \multirow{2}{*}{$\begin{array}{l}\text { Winter } \\
2013\end{array}$} & \multicolumn{2}{|c|}{ Spring } & \multirow[b]{3}{*}{ B } \\
\hline & & & & & & & & & \\
\hline & & $\mathbf{S}$ & B & $\mathbf{S}$ & B & $\mathbf{S}$ & B & $\mathbf{S}$ & \\
\hline \multirow[t]{3}{*}{$\mathrm{NH}_{4} / \mathrm{N}$} & Min. & 9.31 & 5.75 & 46.13 & 7.19 & 8.50 & 1.25 & 4.18 & 4.25 \\
\hline & Max. & 156.25 & 54.56 & 187.00 & 110.00 & 219.13 & 15.81 & 124.13 & 22.13 \\
\hline & Ave. & 46.03 & 18.08 & 74.34 & 25.92 & 99.27 & 4.73 & 49.53 & 10.70 \\
\hline \multirow[t]{3}{*}{$\mathrm{NO}_{2} / \mathrm{N}$} & Min. & 0.80 & 0.02 & 1.12 & 0.25 & 0.74 & 0.12 & 0.10 & 0.18 \\
\hline & Max. & 3.62 & 0.75 & 9.49 & 4.56 & 10.02 & 0.70 & 3.56 & 1.24 \\
\hline & Ave. & 2.05 & 0.46 & 3.26 & 1.27 & 4.34 & 0.36 & 1.77 & 0.72 \\
\hline \multirow[t]{3}{*}{$\mathrm{NO}_{3} / \mathrm{N}$} & Min. & 0.79 & 0.86 & 3.90 & 3.71 & 9.91 & 0.82 & 0.05 & 0.18 \\
\hline & Max. & 1.68 & 3.01 & 9.10 & 8.48 & 66.70 & 11.02 & 2.80 & 2.72 \\
\hline & Ave. & 1.22 & 1.91 & 5.34 & 6.67 & 31.68 & 4.36 & 1.35 & 1.33 \\
\hline \multirow[t]{3}{*}{$\mathrm{TN}$} & Min. & 48.85 & 12.29 & 70.35 & 20.67 & 79.11 & 27.50 & 42.31 & 19.04 \\
\hline & Max. & 212.72 & 56.41 & 255.65 & 209.96 & 812.71 & 86.31 & 334.65 & 93.08 \\
\hline & Ave. & 99.27 & 28.26 & 134.94 & 70.59 & 335.12 & 55.42 & 156.85 & 49.22 \\
\hline \multirow[t]{3}{*}{$\mathrm{PO}_{4} / \mathrm{P}$} & Min. & 2.00 & 0.26 & 2.33 & 0.89 & 0.57 & 0.52 & 0.10 & 0.05 \\
\hline & Max. & 14.87 & 1.28 & 13.66 & 6.68 & 17.36 & 1.29 & 6.73 & 0.46 \\
\hline & Ave. & 4.81 & 0.74 & 4.59 & 2.29 & 7.02 & 0.93 & 2.14 & 0.25 \\
\hline \multirow[t]{3}{*}{ TP } & Min. & 1.96 & 0.41 & 1.61 & 0.40 & 0.89 & 0.11 & 0.52 & 0.39 \\
\hline & Max. & 20.69 & 2.64 & 28.01 & 6.57 & 24.11 & 1.11 & 13.58 & 0.85 \\
\hline & Ave. & 5.11 & 1.65 & 8.05 & 2.02 & 9.78 & 0.64 & 4.32 & 0.63 \\
\hline \multirow[t]{3}{*}{$\mathrm{SiO}_{4}$} & Min. & 16.50 & 7.28 & 14.67 & 10.51 & 2.58 & 0.31 & 1.72 & 0.37 \\
\hline & Max. & 193.71 & 12.61 & 213.09 & 128.33 & 70.72 & 3.40 & 125.32 & 14.33 \\
\hline & Ave. & 65.67 & 10.49 & 78.92 & 35.73 & 31.67 & 2.15 & 42.89 & 4.88 \\
\hline
\end{tabular}




\begin{tabular}{|c|c|c|c|c|c|c|c|c|c|}
\hline & & \multirow{2}{*}{$\begin{array}{l}\text { Summer } \\
2012\end{array}$} & \multicolumn{3}{|c|}{ Autumn } & \multirow{2}{*}{$\begin{array}{l}\text { Winter } \\
2013\end{array}$} & \multicolumn{2}{|c|}{ Spring } & \multirow[b]{3}{*}{ B } \\
\hline & & & & & & & & & \\
\hline & & $\mathbf{S}$ & B & $\mathbf{S}$ & B & S & B & $\mathbf{S}$ & \\
\hline \multirow[t]{3}{*}{ Chl-a } & Min. & 1.92 & 0.19 & 0.52 & 0.60 & 1.07 & 0.52 & 1.91 & 1.03 \\
\hline & Max. & 9.62 & 3.58 & 14.72 & 2.81 & 30.92 & 1.88 & 144.43 & 25.51 \\
\hline & Ave. & 4.71 & 1.74 & 4.78 & 1.49 & 7.51 & 1.04 & 37.55 & 11.59 \\
\hline
\end{tabular}
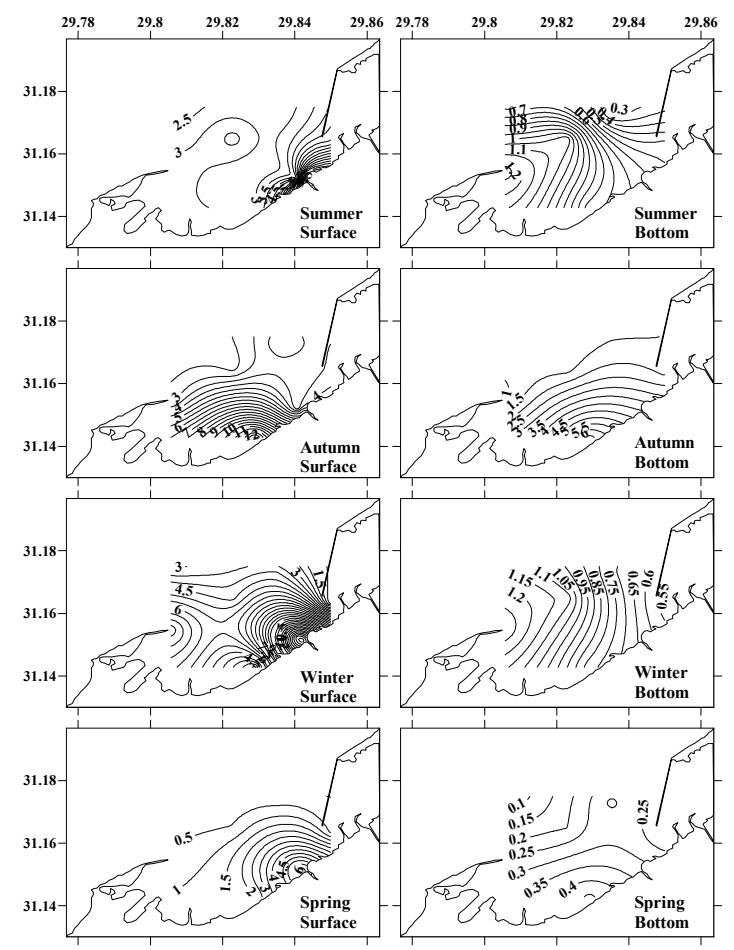

Figure 6. Horizontal distribution of $\mathrm{PO}_{4} \mathrm{P}$ concentration $(\mu \mathrm{M})$ in surface and bottom water, El-Mex Bay during 2012-2013.

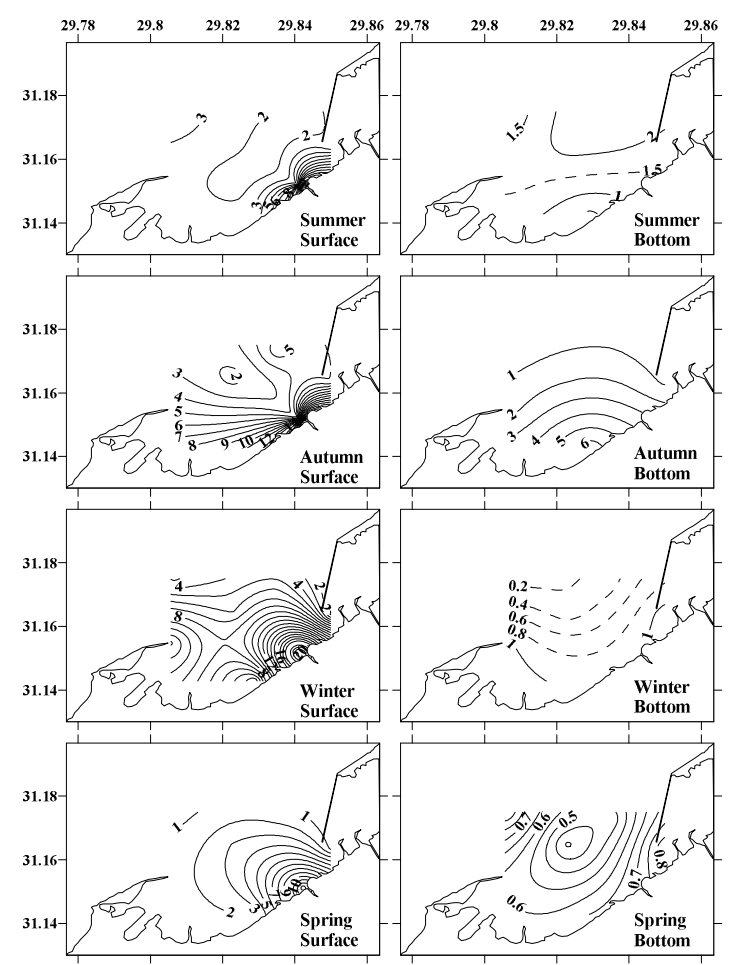

Figure 7. Horizontal distribution of TP concentration $(\mu M)$ in surface and bottom water, El-Mex Bay during 2012- 2013.

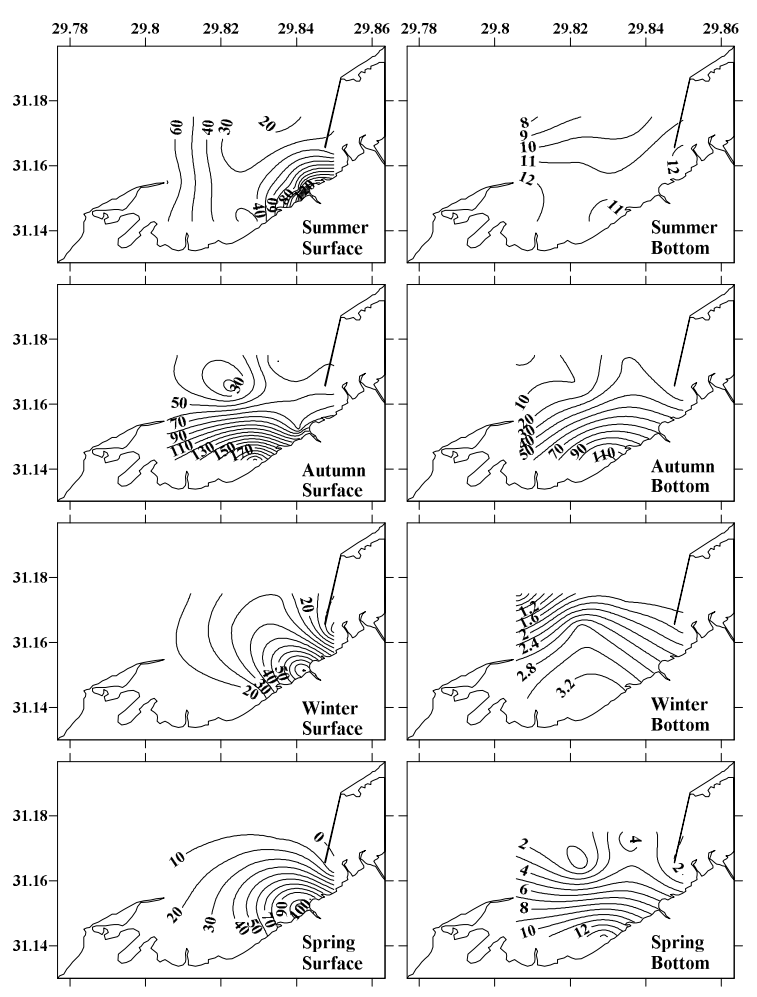

Figure 8. Horizontal distribution of $\mathrm{SiO}_{4}$-Si concentration $(\mu \mathrm{M})$ in surface and bottom water, El-Mex Bay during 2012- 2013.
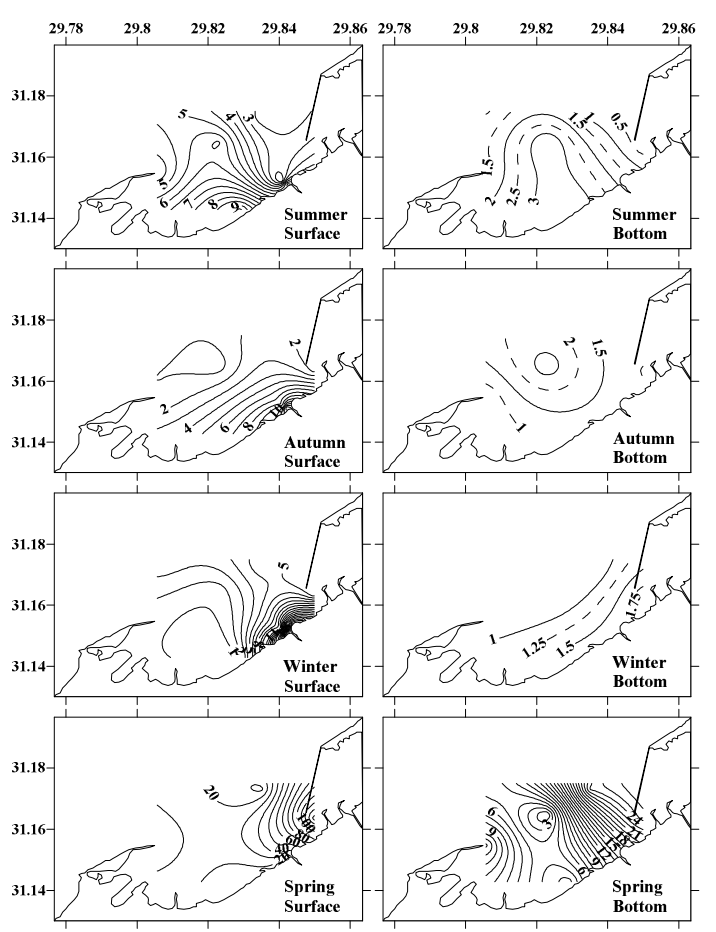

Figure 9. Horizontal distribution of Chl-a $\left(\mu g l^{-1}\right)$ in surface and bottom water, El-Mex Bay during 2012-2013. 
The horizontal distribution of Chl-a content is presented in Figure 9. In summer 2012, surface water Chl-a content increased from north to south near El-Umum drain and in summer2012 bottom water, it increased from north and western south to south eastern. In autumn bottom water 2012, Chl-a increased from middle to south and to north. In autumn bottom 2012, it increased western south to the north near ElUmum drain. In winter and spring surface and bottom water, in winter 2013 at surface, it increased from western north to the south near El-Umum drain, while it decreased from eastern south to the western south in bottom water. In spring 2013, Chl-a concentration increased toward the eastern south.

\section{Conclusion}

El Mex Bay is one of the major areas in Alexandria, Egypt; local communities used this Bay for fishing activities. From the results of this study, the evaluation and characterization of water quality reflects the impacts of anthropogenic activities on quality of seawater. However, the continuous build-up of the nutrient salt contaminants can be checked if relevant government agencies ensure strict compliant of wastewater treatment before discharging such contaminated effluents/wastes into the bay. Therefore, perpetual assessment is highly recommended to minimize the potential health hazards of the people who surely depend on fishing purposes.

\section{References}

[1] Islam M. S. and Tanaka M. (2004). Impacts of pollution on coastal and marine ecosystems including coastal and marine fisheries and approach for management: a review and synthesis. Marine Pollution Bulletin 48: 624-649.

[2] El-Saeedy M. A. E. (2007). Evaluation of the BOD Measurement of some organic wastes mixed with different water types. M.Sc. Thesis of Public Health Sciences, High Institute of Public and Health, Alexandria University, Egypt.

[3] GESAMP (IMO/FAO/UNESCO/WMO/IAEA/UN/UNEP); Joint Group Experts on the, Scientific Aspects of Marine Pollution (1993), "Impacts of oil and released chemicals and wastes on the marine environment": Reports and studies No. 50, International Maritime Organization, London.

[4] Vaalgamaa S. (2004). The effect of urbanization on Laajalahti Bay, Helsinki City, as reflected by sediment geochemistry. Marine Pollution Bulletin 48: 650-662.

[5] Hass P. (2002). Environment: Pollution. In: Simmons. P. J. and Oudraat. C. J. (eds). Managing Global Issues: Lessons learned. Washington, DC: Carnegie Endowment for International Peace, 310-53.

[6] Kress N., Manca. B. B., Klein. B. and Deponte. D. (2003). Continuing influence of the changed thermohaline circulation in the eastern Mediterranean on the distribution of dissolved oxygen and nutrients: Physical and chemical characterization of the water masses,J. Geophys. Res., 108, 8109.

[7] Pujo-Pay M., Conan. P., Oriol. L., Cornet-Barthaux. V., Falco. C., Ghiglione. J.-F., Goyet. C., Moutin. T., and Prieur. L.
(2011). Integrated survey of elemental stoichiometry (C,N,P) from the western to eastern Mediterranean Sea, Biogeosciences, 8, 883-899.

[8] Tanhua T., Hainbucher. D., Schroeder. K., Cardin. V., Alvarez. M. and Civitarese. G. (2013). The Mediterranean Sea system: a review and an introduction to the special issue. Ocean Sci., 9, 789-803.

[9] Huertas I. E., Rios. A. F., Garcia-Lafuente. J., Navarro. G., Makaoui. A., Sanchez-Roman. A., Rodriguez-Galvez. S., Orbi. A., Ruiz. J., and Perez. F. F. (2012). Atlantic forcing of the Mediterranean oligotrophy, Global Biogeochem. CY. 26, 2022.

[10] WHO. (2002). Eutrophication and health.

[11] Abdel-Rhman M. Kh. (2013). Distribution of Nutrient Salts in hot spot areas at El-Mex Bay (Egyptian Mediterranean Sea) In relation to physicochemical parameters. Ms. c Thesis. Fac. Sc., Alex. Univ.

[12] Mahamoud Th. H., Masoud M. S., Shaltout N. A. (2008). Physico- chemical characteristics of different water type in ElMex Bay, Alexandria, Egypt.

[13] Said M. A., El-Deek M. S., Mahmoud. Th. H. and Shriadah. M. A. (1994). Effect of pollution on the hydrochemical characteristics of different water types in El-Max Bay area, west of Alexandria, Egypt. ActaAdriatica, 34 (1/2): 9-19.

[14] Tayel F. T., Fahmy. M. A. and shriadah. M. A. (1996). Studies of physicochemical characteristic of el-mex bay and new dekhela harbor of Alexandria. bull. Nat. inst. Oceanogr\&fish., A. R. E., 22: 1-18.

[15] Abd-Alla A. M. (2007). Speciation of Trace Metals in Coastal Sediments of El-MexBay South Mediterranean Sea-West of Alexandria (Egypt). Environ Monit Assess, 132:111-123.

[16] Grasshoff K. (1983). Methods of seawater analysis. VerlagChemie, Weinheim, New York.

[17] FAO (1976). Manual of Methods in Aquatic Environmental Research, Part I: Permanganate value (oxidiability) of organic matter in natural waters. Fisheries Technical Paper, 1378: 169.

[18] Strickland H. D. and Parsons, T. R. (1972). A practical handbook of sea water analysis. Fish. Res. Bd. Canada Bull., 157, 2nd ed.:310.

[19] Valderrama J. C. (1981). The simultaneous analysis of total nitrogen and total phosphorus in natural waters. Marine Chemistry, 10: 109-122.

[20] International Oceanographic Commission (IOC) (1983). Chemical methods for use in marine environmental monitoring. Manuals and Guides. UNESCO, 53.

[21] Edwards A. J. and Head S. M. (1987). Red Sea, Keu Environmental Series, Pergamon Press, Oxford, UK.

[22] Stumm W. and Morgan. J. J. (1970). Aquatic chemistry, an introduction emphasizing chemical equlibria in natural waters. Wiley-interscience. Inc. New York, London, Sydney and Toronto. 583.

[23] Duursma E. K. (1961). Dissolved organic Carbon, Nitrogen and Phosphorus in the Sea NeTherl. J. Sea Res., 1(1-2), 1-141.

[24] Prosi and VanLierde. J. H. (1983). Metal Pollution in the Aquatic Environment Springer. Verlag Berlin, Heidelberg, New York, Tokyo. 
[25] Elewa A. A. and Ghalab. M. H. M. (2001). Water sediment interaction in the River Nile at Rossetta branch in front of ElRahawy drain, Egypt. Life Environ. 422-442.

[26] Meade J. W. (1985). Allowable ammonia for fish culture. Prog. Fish. Cult. 47, 135-145.

[27] Barat S and Jana. B. B. (1987). Effects of farming management on the distribution pattern of ammonification rate, protein mineralizing and ammonifying bacterial population in experimental culture tanks. Bamidgeh 39, 120 132.

[28] Weimer W. and Lee. G. F. (1973). Limnol. Oceanogr., 18, 414-425.

[29] APHA (1995) American Public Health Associations. Standard Methods for The Examination of Water and Wastewater.19th edition, New York.

[30] Munawar M. (1970). Limnological Studies on Fresh Water Ponds of Hyderabad, India, I. The Biotope. Hydrobiol., 35: 127-163.

[31] Seike Y. J., Kondo K., Hashihitani. H., Okumura. M., Fujinya. K. and Date. Y. (1990). "Nitrogen metabolism in brackish lake nakanoum. IV; Seasonal variation of nitrate-nitrogen". Jpn. J. Limnol. 51(3), 137-147.
[32] EPA. (2013). Environmental Protection Agency. United State.

[33] Okbah M. A. (2005). Nitrogen and Phosphorus species of lake burullus water (Egypt). Egyptian journal of aquatic research, 31,1 .

[34] Vanloon G. W. and Duffy. S. J. (2000). In "Environmental Chemistry" A Global.

[35] Abou-El-Khair E. M. (1993). Chemical studies on the Mediterranean coastal water in front of the rosetta mouth of the Nile. M. Sc. Fac. Sc., Alex. Univ. Chemical Oceanogrphy Depepartment. Egypt.

[36] Saad M. A. (1973). Hydrobiologia, 41:477-499.

[37] Baiely-Watts A. E. (1976). Planktonic diatoms and some diatom silica relation in a shallow eutrophic scottish lake fresh water. Biol., 69-80.

[38] Dickson E. L. (1975). A Silica Budget for Lough Neagh 19701972. Freshwater Biology, 5, 1-12.

[39] Sawsan M. A., Nagwa. E. A., Mohamed. M. A., El Raey. M. and Hamdy. A. A. (2014). Environmental assessment of ElMex Bay, South-eastern Mediterranean by using Rotifera as a plankton bio-indicator. Egyptian Journal of Aquatic Research. 40: 43-57. 